\title{
Development and collapse of a Gymnodinium mikimotoi red tide in the Seto Inland Sea
}

\author{
Yasuo Nakamura ${ }^{1, *}$, Shin-ya Suzuki ${ }^{2}$, Juro Hiromi ${ }^{2}$ \\ 'National Institute for Environmental Studies, Tsukuba, Ibaraki 305, Japan \\ ${ }^{2}$ College of Agriculture and Veterinary Medicine, Nihon University, Fujisawa, Kanagawa 252, Japan
}

\begin{abstract}
A red tide due to Gymnodinium mikimotoi (Dinophyceae) occurred at Harima-nada, the Seto Inland Sea (Japan), in summer 1995. Throughout the development and collapse of the red tide, abundance of G. mikimotoi and its potential predators (heterotrophic dinoflagellates and ciliates) was monitored daily together with environmental variables. While a nitrate and phosphate cline was present at around $15 \mathrm{~m}, \mathrm{G}$. mikimotoi concentrations increased rapidly for about a week in the subsurface layer $(5$ to $15 \mathrm{~m})$ Then the population suddenly accumulated at the surface layer in the daytime and formed a red tide (ca $3 \times 10^{3} \mathrm{ml}^{-1}$ ). Following the red tide formation, the abundance of naked heterotrophic dinoflagellates ( $\mathrm{h}$-dinos) started to increase. Subsequently, the abundance of the tintinnid clliate Favella ehrenbergii increased $\left(\mathrm{ca} 10 \mathrm{ml}^{-1}\right.$ ) and apparently consumed $G$. mikimotoi and h-dinos completely within a few days. On the basis of these results, the ecological differences between $G$. mikimotoi and Chattonella antiqua (Raphidophyceae; another representative red tide forming species in the Seto Inland Sea) are discussed, as well as the importance of microzooplankton grazing for the collapse of red tides.
\end{abstract}

KEY WORDS: Red tide Gymnodinium Microzooplankton Ciliate - Tintinnid Heterotrophic dinoflagellate

\section{INTRODUCTION}

Gymnodinium mikimotoi Miyake et Kominami ex Oda, conspecific with G. nagasakiense (Takayama \& Matsuoka 1991), is a naked autotrophic dinoflagellate and is closely related to Gyrodinium aureolum (Hulburt) (Partensky et al. 1988). While G. aureolum blooms in the North Sea and in coastal waters around European countries, the United States and Argentina (e.g. Pingree et al. 1975, Jones et al. 1982, Chang \& Carpenter 1985, Jiménez et al. 1992, Negri et al. 1992), G. mikimotoi forms severe red tides in the coastal waters around Japan and Korea during warm seasons (e.g. Iwasaki et al. 1990, Honjo 1994). Red tides by G. mikimotoi have killed farmed fish. For example, the damage reached 4.4 billion yen in a red tide which occurred in Kumano-nada, Japan, in 1984 (Honjo 1994).

In the last 3 decades, many ecological and physiological studies on Gymnodinium mikimotoi and Gyro-

•E-mail:yasuo@nies.go.jp dinium aureolum have been conducted (Honjo 1994 and references therein). However, to our knowledge, no previous studies have dealt with the population development and collapse of G. mikimotoi or G. aureolum on a daily basis together with the changes in environmental variables and potential predators. We present here the wax and wane of a G. mikimotoi red tide that occurred in the Seto Inland Sea in summer 1995, relative to the changes in environmental variables (e.g. temperature, salinity, nutrients) and microzooplankton (heterotrophic dinoflagellate and ciliate) populations. The main aim of the present study was to explain the outbreak mechanisms of G. mikimotoi red tide when the water was thermally stratified and to assess the roles of microzooplankton populations in the disappearance of the red tide.

\section{METHODS}

In summer 1995 (15 July to 8 August), a field survey was conducted at Stn B $\left(34^{\circ} 35^{\prime} \mathrm{N}, 134^{\circ} 30^{\prime} \mathrm{E}, 21 \mathrm{~m}\right.$ 
depth; see Nakamura et al. 1993) around the Ie-shima Islands in the Seto Inland Sea. Water temperature, salinity, and dissolved oxygen were monitored at $2.5 \mathrm{~m}$ intervals using a Surveyor II (Hydrolab Co.). Water samples for chemical analysis $\left[\mathrm{NO}_{3}^{-}, \mathrm{NO}_{2}{ }^{-}, \mathrm{NH}_{4}{ }^{*}\right.$. $\mathrm{PO}_{4}{ }^{3-}, \mathrm{Si}(\mathrm{OH})_{4}$, chlorophyll a (chla)] and Gymnodinium mikimotoi enumerations were taken at depths of $0,5,10,15$ and $19 \mathrm{~m}$ using a $10 \mathrm{l}$ Van Dorn-type bottle. Samples for microzooplankton enumeration were taken at 0 and $10 \mathrm{~m}$. Monitoring and sampling were conducted daily in the morning (06:20 to 07:00 h). Samples for nutrients $(100 \mathrm{ml})$ and chl a $(500 \mathrm{ml})$ were filtered through GF/F filters immediately after sampling, stored at $-20^{\circ} \mathrm{C}$, and analyzed after the completion of the field survey. Nutrients were analyzed with a Technicon Auto Analyzer II for $\mathrm{PO}_{4}{ }^{3-}$ (Murphy \& Riley 1962), $\mathrm{NH}_{4}{ }^{+}$(Solórzano 1969), $\mathrm{NO}_{2}{ }^{-}$(Bandschneider \& Robinson 1952), $\mathrm{NO}_{2}^{-}+\mathrm{NO}_{3}^{-}$(Wood et al. 1967) and $\mathrm{Si}(\mathrm{OH})_{4}$ (Strickland \& Parsons 1968). Chl a was measured fluorometrically (Yentsch \& Menzel 1963).

Abundance of Gymnodinium mikimotoi was measured by observing $1 \mathrm{ml}$ intact samples in a Sedgewick-Rafter chamber under a microscope within 90 min after collection. Before enumeration, samples were vigorously mixed to slow down the movement of G. mikimotoi cells

Samples $(80 \mathrm{ml})$ for microzooplankton enumeration were fixed with glutaraldehyde (final conc. 1\%), stored at $5^{\circ} \mathrm{C}$ for $1 \mathrm{~h}$ and stained with DAPI (final conc.. 1. $\mu \mathrm{g} \mathrm{ml}^{-1}$; Porter \& Feig 1980) Then subsamples of $20 \mathrm{ml}$ were concentrated onto $0.8 \mu \mathrm{m}$ pore size black Nuclepore filters $(25 \mathrm{~mm} \varnothing)$ under low $(<100 \mathrm{~mm} \mathrm{Hg}$ ) vacuum. The filters were observed with a Nikon epifluorescence microscope equipped with an $\mathrm{Hg} 100 \mathrm{~W}$ lamp and appropriate exciter/barrier filter sets for UV (330 to $380 \mathrm{~nm}$ ) and blue (450 to $490 \mathrm{~nm}$ ) excitation. The following plankton categories were enumerated for sizes of 20 to $40 \mu \mathrm{m}$ and 40 to $200 \mu \mathrm{m}$ in length: naked heterotrophic dinoflagellates (h-dinos), thecate h-dinos, the heterotrophic silicoflagellate Ebria tripartia, naked ciliates (excluding Mesodinium rubrum) and tintinnids. Autotrophic and heterotrophic cells were identified by the presence or absence of autofluorescent chloroplasts. Dinoflagellates were distinguished from other flagellates based upon morphology and structure of the nucleus and cell morphology (Verity et al. 1993). Ciliates were distinguished from other protozoa by shape, the presence of cilia and the presence of multiple dimorphic nuclei (Sherr et al. 1986). Microzooplankton populations were enumerated at $\times 200$ by observing 100 to 130 fields $(970 \mu \mathrm{m} \varnothing)$, and thus the detection limit was $0.2 \mathrm{ml}^{-1}$ (volume of filtration $=20 \mathrm{ml}$, filtration area $=17 \mathrm{~mm} \varnothing$ ).

Cell sizes of Gymnodinium mikimotoi and Favella ehrenbergii were measured $(\mathrm{n}=100)$ in acid Lugol fixed samples (2\%) from 29 July $(10 \mathrm{~m})$ and 4 August $(0 \mathrm{~m})$, respectively, using an inverted microscope $(\times 200)$.

\section{RESULTS}

\section{Environmental conditions and development of the red tide}

The weather was sunny and calm throughout the survey period except on 17 and 22 July, when some precipitation was recorded. The water was thermally stratified (Fig. 1) and salinity ranged between 30.3 and 33.0 ppt. As the development of anoxic bottom water has been suggested to play an important role in the development of Gymnodinium mikimotoi red tides (lizuka \& Irie 1969, Iizuka 1972), it should be noted that dissolvcd oxygen at $20 \mathrm{~m}$ depth (1. $\mathrm{m}$ above the bottom) exceeded 4.0 ppm from 15 July to 5 August, with a minimum of 3.5 ppm on 8 August.

The abundance of Gymnodinium mikimotoi averaged over the water column started to increase on 23 July, increased at a rate $\left(0.63 \mathrm{~d}^{-1}\right)$ close to 1 doubling $\mathrm{d}^{-1}$, reached a maximum of $380 \mathrm{ml}^{-1}$ on $30 \mathrm{July}$, and then sharply decreased (Fig. 2A). From 23 to 30 July when $G$. mikimotoi concentrations increased, cells were most abundant between depths of 10 and $15 \mathrm{~m}$ in the morning (Fig. 2B). A dense accumulation of cells in the surface layer (red tide) was not observed until the afternoon of 29 July. From 30 July to 3 August, G. mikimotoi cells were most abundant at the surface in the morning

Phytoplankton other than Gymnodinium mikimotoi. From 15 to 17 July, Skeletonema costatum was dominant (not enumerated) throughout the water column. Then the abundance of $S$. costatum decreased and Ceratium furca and Distephanus speculum became abundant in the surface layer from 18 to 26 July (data

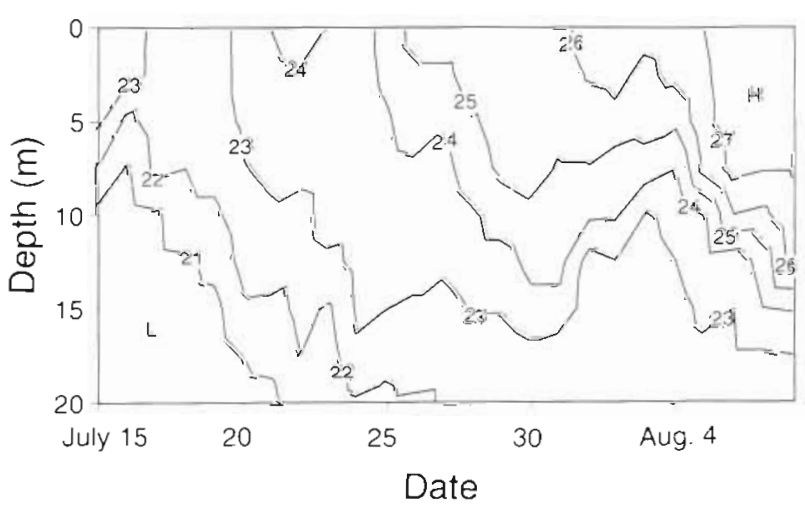

Fig. I Vertical and temporal changes in water temperature $\left({ }^{\circ} \mathrm{C}\right)$ at $\operatorname{Stn} \mathrm{B}$ 

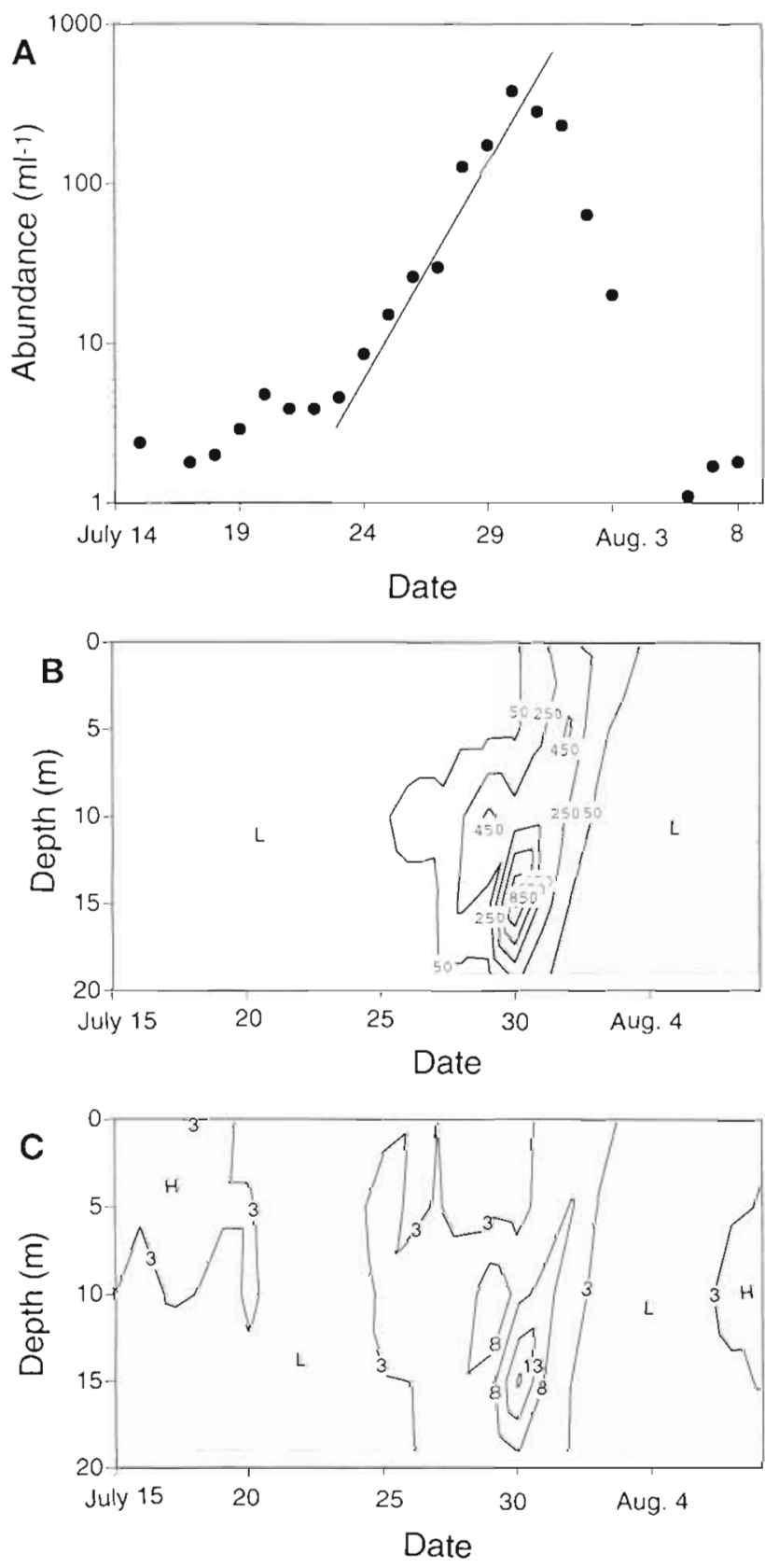

Fig. 2. Red tide formed by Gymnodinium mikimotoi. (A) Temporal changes in the abundance of $G$. mikimotoi $\left(\mathrm{ml}^{-1}\right)$ averaged over the water column; (B) vertical and temporal changes in the abundance of G. mikimotoi $\left(\mathrm{ml}^{-1}\right)$ and (C) chlorophyll a $\left(\mu \mathrm{g} \mathrm{I}^{-1}\right)$. H: high; L: low

not shown). However, the phytoplankton was completely dominated by Gymnodinium mikimotoi at depths of 10 to $15 \mathrm{~m}$ from 26 to 30 July, throughout the water column from 31 July to 1 August, and at 0 to $10 \mathrm{~m}$ from 2 to 3 August. After the collapse of the G. mikimotoi red tide, Chaetoceros spp. became dominant. Chl a was within the range 0.6 and $18.9 \mathrm{\mu g} \mathrm{l}^{-1}$ and the maximum was observed at $15 \mathrm{~m}$ on $30 \mathrm{July}$ (Fig. 2C).
Nutrients. Coupled with the thermal stratification of the seawater, concentrations of nitrate and phosphate were generally low at depths of 0 to $5 \mathrm{~m}$. Clines for these nutrients were present in the 10 to $15 \mathrm{~m}$ layer when the Gymnodinium mikimotoi population developed (Fig. 3A, B). The level of ammonium was usually around $1 \mu \mathrm{M}$ (Fig $3 \mathrm{C}$ ), and a slight increase was observed just after the collapse of the red tide. Silicate was always higher than $13 \mu \mathrm{M}$ throughout the water column until 4 August, and then decreased sharply to ca $3 \mu \mathrm{M}$ at 0 to $10 \mathrm{~m}$ depth (data not shown) in accordance with the development of diatoms (see above).
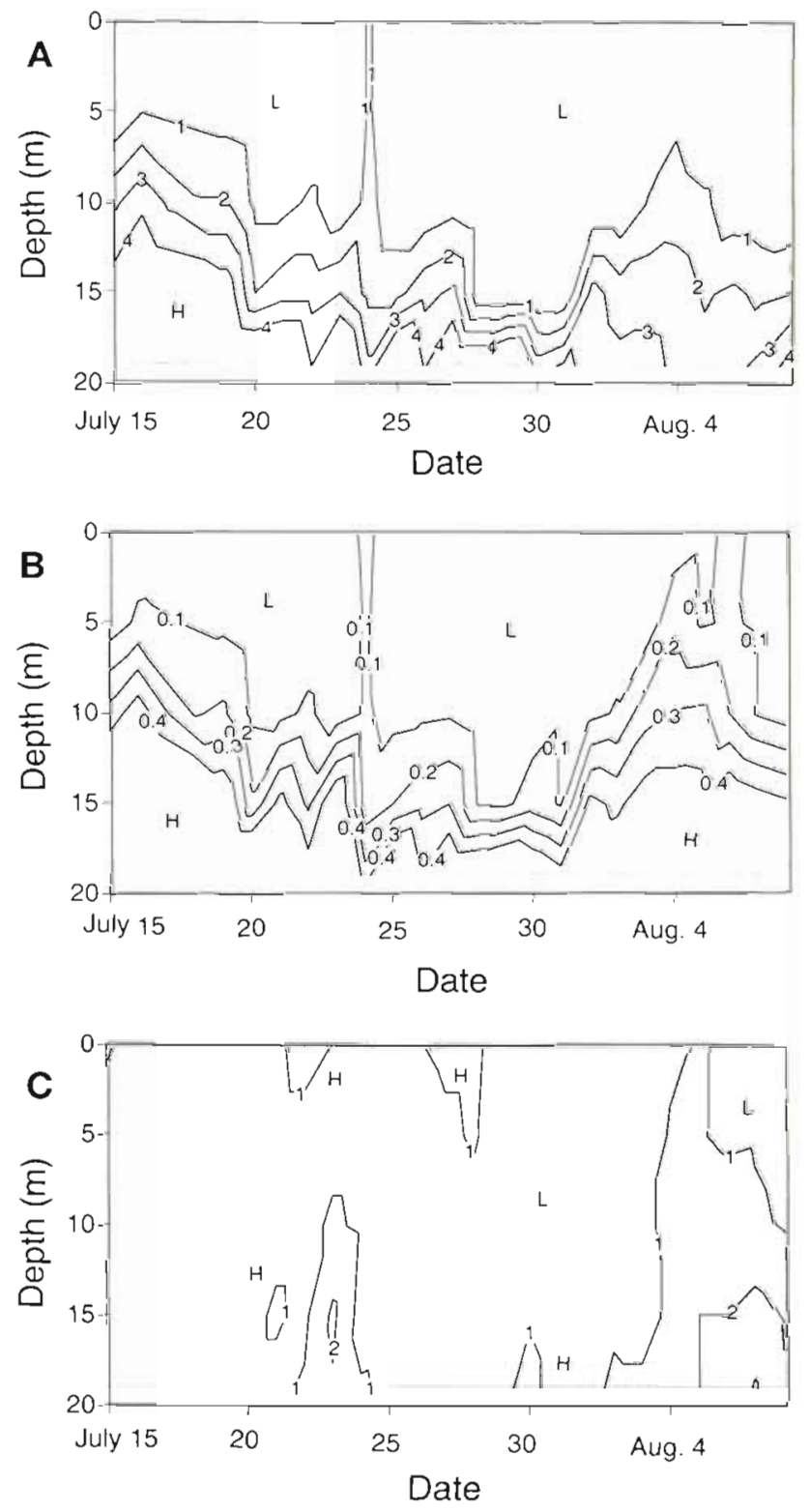

Fig. 3. Vertical and temporal changes in (A) nitrate $(\mu M),(B)$ phosphate $(\mu \mathrm{M})$, and $(\mathrm{C})$ ammonium $(\mu \mathrm{M}) . \mathrm{H}$ : high; L: low 


\section{Microzooplankton}

Heterotrophic dinoflagellates. Throughout the survey period, dominant species of naked h-dinos were Gyrodinium dominans and $G$. spirale for the 20 to 40 and $>40 \mu \mathrm{m}$ size classes, respectively, as confirmed by the observations of live samples. The abundance of naked h-dinos was relatively constant during the period of red tide development, started to increase on 30 July (the peak of Gymnodinium mikimotoi abundance; cf. Fig. 2), reached a peak on 2 August, and then decreased sharply together with the collapse of the red tide (Fig. 4A, B). From 1 to 3 August, naked h-dinos that contained a large food vacuole $(>10 \mu \mathrm{m})$ with red autofluorescence were often observed (not precisely enumerated, but accounting for some $10 \%$ of total naked h-dinos cells).

The abundance of thecate h-dinos was much lower than that of naked cells and no systematic trends were observed (data not shown).
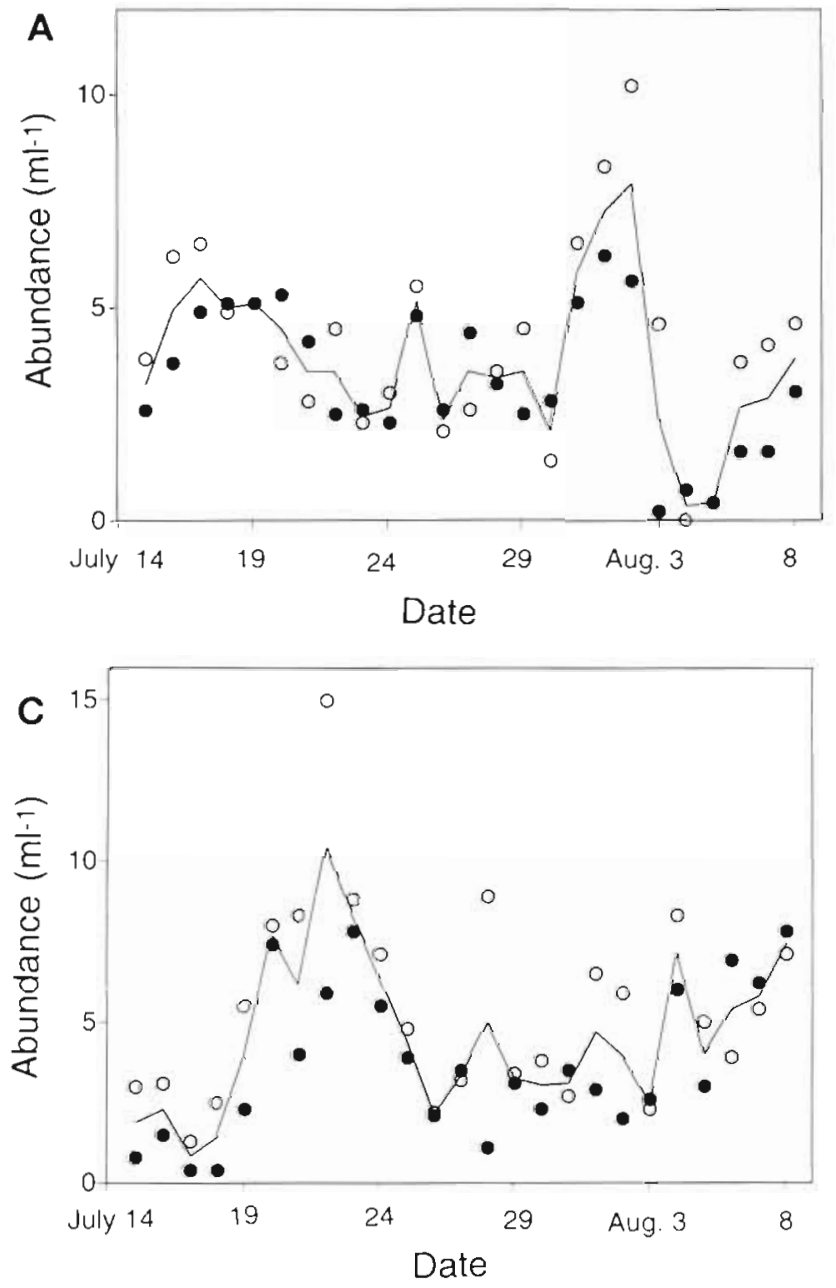

Ciliates. Oligotrichs were numerically abundant among naked ciliate populations. Cone-shaped mixotrophic oligotrichs ca $40 \mu \mathrm{m}$ and ca $90 \mu \mathrm{m}$ in size were the dominant ciliates throughout the survey period and the smaller ciliates were more abundant. Although 2 peaks of naked ciliates were observed (20-24 July and 7-8 August), they did not respond to the outbreak of Gymnodinium mikimotoi red tide (Fig. 4C). Throughout the red tide, naked ciliate cells with fluorescent red food vacuoles $(>10 \mu \mathrm{m})$ were not observed.

In July, tintinnids were less abundant than naked ciliates, and cells with an oral lorica diameter of less than $30 \mu \mathrm{m}$ were dominant. Favella ehrenbergii (ca $65 \mu \mathrm{m}$ in oral lorica diameter; identified by Y. O. Kim) was first observed on 31 July and accounted for $>95 \%$ of tintinnid ciliate cells $\mathrm{ml}^{-1}$ from 1 to 6 August. The abundance of tintinnids started to increase sharply on 31 July, reached a maximum on 3 August and then decreased (Fig. 4D). F. ehrenbergii was abundant at
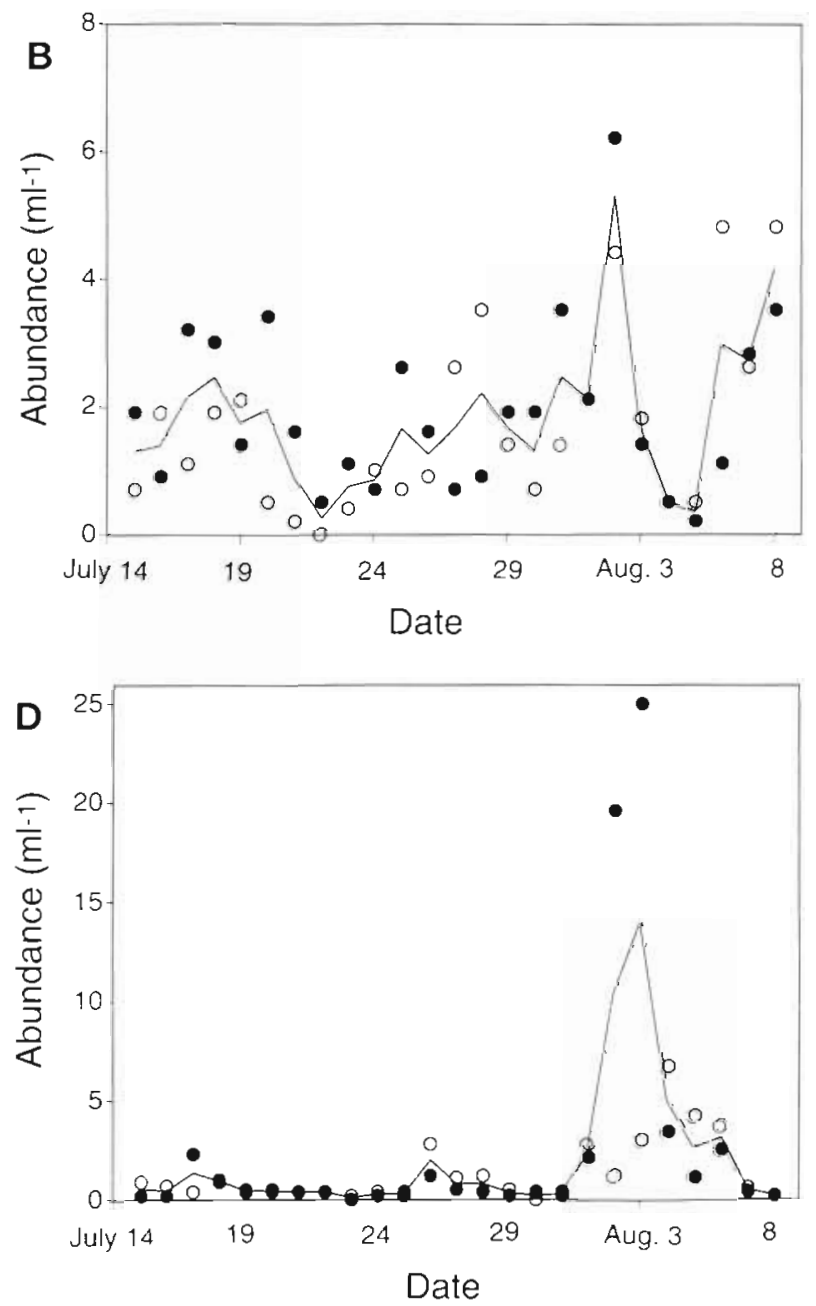

Fig. 4 Changes in the abundance $\left(\mathrm{ml}^{-1}\right)$ of $(\mathrm{A})$ naked heterotrophic dinoflagellates with sizes of 20 to $40 \mu \mathrm{m}$, (B) naked heterotrophıc dinoflagellates with sizes of 40 to $200 \mu \mathrm{m}$, (C) naked ciliates with sizes of 20 to $200 \mu \mathrm{m}$, and (D) tintinnids. (O) Values at $0 \mathrm{mi}(\bullet)$ values at $10 \mathrm{~m} ;(-)$ averaged values between 2 depths 
$10 \mathrm{~m}$ in the morning but accumulated at the surface around noon (data not shown). From 31 July to 3 August most $F$. ehrenbergij cells were filled with food vacuoles apparently originating from Gymnodinium mikimotoi

Ebria tripartia. The abundance of the heterotrophic silicoflagellate Ebria tripartia (ca $35 \mu \mathrm{m}$ ) was high (2 to $4 \mathrm{ml}^{-1}$ ) from 16 to 20 July when a diatom Skeletonema costatum was abundant, and decreased to $<1 \mathrm{ml}^{-1}$ thereafter (data not shown). Ebria cells attached to $S$. costatum were often observed.

\section{DISCUSSION}

We have monitored the marine environment during summer around the Ie-shima Islands since 1985 and have encountered Gymnodinium mikimotoi red tides twice (1994 and 1995). Although studies of the red tide of 1994 provided information on its collapse due to microzooplankton grazing (Nakamura et al. 1995b), its sudden occurrence, due probably to advection, made it difficult to relate the population development with changes in chemical/physical variables. Thus, to our knowledge, the present data obtained in 1995 are the first to describe the development of a $G$. mikimotoi red tide together with changes in environmental variables and predators at short time intervals.

\section{Population development}

One feature of the red tide in 1995 was that Gymnodinium mikimotoi did not accumulate in the surface layer in the daytime during the bloom development period (Fig. 2), as was observed in the red tide that occurred in Gokasho Bay (Honjo et al. 1990). A dense accumulation of Gyrodinium aureolum, closely related to $G$. mikimotoi, at a pycnocline was also observed in the Kattegat, Denmark (Bjørnsen \& Nielsen 1991). Since nutrient concentrations at and above $10 \mathrm{~m}$ were very low [e.g. $\mathrm{NO}_{3}{ }^{-}<0.2 \mu \mathrm{M}$ except 24 July $(0$ to $10 \mathrm{~m})$ and 27 July $(10 \mathrm{~m})$; Fig. 3] during the period of bloom development (23 to 30 July; Fig. 2A), we infer that the ability of $G$. mikimotoi to remain in the subsurface layer makes it easier for the organism to reach the nutrient-sufficient layer at night: $G$. mikimotoi shows diurnal vertical migration at a speed of 1 to $2 \mathrm{~m} \mathrm{~h}^{-1}$ (Koizumi et al. 1996) and $G$. aureolum can take up nitrate at night (Paasche et al 1984, Dixon \& Holligan 1989). Thus it is reasonable to speculate that $G$. mikimotoi present at $10 \mathrm{~m}$ in the morning (Fig. 2B) ascends to $5 \mathrm{~m}$ (above the Secchi depth) around noon to photosynthesize actively, and then descends to ca $15 \mathrm{~m}$ at night (close to or below the nutrient cline) and takes up nutrients for growth. However, this scenario is applicable only when $G$. mikimotoi can take up nutrients at night. Nutrient uptake and growth kinetics of this species as a function of nutrient concentration and light conditions deserve further study.

In the Seto Inland Sea, Chattonella antiqua (Raphidophyceae) is another representative organism that forms red tides in summer (Honjo 1994). This species can take up nutrients at night (Nakamura \& Watanabe 1983) and accumulates in the surface layer during the day and at around $10 \mathrm{~m}$ at night (Nakamura et al. 1989). These characteristics enable $C$. antiqua to propagate when the nutrient cline is present above $10 \mathrm{~m}$ (Nakamura et al. 1989). In contrast, in years when the nutrient cline was deeper than $10 \mathrm{~m}$, we have not observed red tides by this species around the Ie-shima Islands (Nakamura unpubl.). This was possibly because $C$. antiqua could not reach the nutrient-sufficient layer at night and could not take up sufficient nutrients for growth. Thus the ability of Gymnodinium mikimotoi to remain in the subsurface layer in the daytime and to migrate downward at night seems to give it an ecological advantage over $C$. antiqua when the nutrient cline is present at a depth below $10 \mathrm{~m}$.

During the bloom development period, predators for Gymnodinium mikimotoi were restricted to naked hdinos (cf. Nakamura et al. 1995a, b): Favella ehrenbergii were below the detection limit $\left(<0.2 \mathrm{ml}^{-1}\right)$, naked ciliates with sizes of ca $40 \mu \mathrm{m}$ or smaller cannot ingest G. mikimotoi (Nakamura et al. 1995b). Copepods (adult + copepodites) were minimal during the survey period $\left(<10 \mathrm{l}^{-1}\right.$; K. Suzuki \& J. Hiromi unpubl.) and furthermore some copepods reject $G$. mikimotoi as food (Uye \& Takamatsu 1990). We calculated the grazing impact of h-dinos on $G$. mikimotoi during this period using an equation presented in a previous study (see Nakamura et al. 1995b). The calculated values indicated that h-dinos populations grazed ca $10 \%$ of the G. mikimotoi population per day. This suggests that h-dinos had a minor effect on the development of the red tide and is probably reflected in the fact that $G$. mikimotoi apparently grew at a rate $\left(0.63 \mathrm{~d}^{-1}\right)$ close to the maximum growth rate $\left(0.69 \mathrm{~d}^{-1}\right.$; lizuka \& Mine 1983, Yamaguchi \& Honjo 1990) obtained in laboratory cultures.

In the afternoon of 29 July, Gymnodinium mikimotoi accumulated in the surface layer and formed a red tide. The red tide occurred almost simultaneously (29 to 30 July) all around the Harima-nada (S. Nagai pers. comm.), suggesting that advection had a minor effect on the outbreak around the Ie-shima Islands. Although the physiological mechanisms responsible for the surface accumulation are still uncertain, escape from selfshading might be one explanation. 


\section{Collapse of the red tide}

For the Gymnodinium mikimotoi red tide of 1994, evidence was presented suggesting that h-dinos, especially Gyrodinium dominans and Gyrodinium spirale, contributed significantly to its disappearance (Nakamura et al. 1995b). In contrast, in the red tide of 1995. we conclude that the tintinnid ciliate Favella ehrenbergii played a major role in the disappearance, based on the following considerations. First, the timing of the collapse of the red tide and the rapid increase in $F$. ehrenbergii abundance overlapped. Furthermore, if we assume that the population of $G$. mikimotoi at the peak (30 July; abundance $=380 \mathrm{ml}^{-1}$, equivalent spherical diameter $(E S D)=19 \mu \mathrm{m}$ ) was all converted to that of $F$. ehrenbergii (ESD of the body $=49 \mu \mathrm{m}$ ) with a gross growth efficiency of 0.4 , the abundance of $F$. ehrenbergii would attain $10 \mathrm{ml}^{-1}$, close to the observed value (Fig. 4D). Second, $F$, ehrenbergii cells were filled with large food vacuoles (>10 $\mu \mathrm{m}$ ) that fluoresced red when $G$. mikimotoi was abundant, whereas after the disappearance of the red tide, no such vacuoles were evident. Third, tintinnids can ingest particles up to $45 \%$ of the oral lorica diameter (Spitter 1973, Heinbokel 1978), and particles close to the maximum size are usually ingested at higher rates than smaller particles (Rassoulzadegan 1978, Stoecker et al. 1995). Thus G. mikimotoi $(28 \times 27 \times 9 \mu \mathrm{m} ; \mathrm{ESD}=19 \mu \mathrm{m})$ could be a suitable food item for $F$. ehrenbergii (oral diameter = ca $65 \mu \mathrm{m})$. Fourth, the body volume specific clearance rate of tintinnids is ca $1 \times 10^{5} \mathrm{~h}^{-1}$ (Neuer \& Cowles 1995), comparable to that of $G$. dominans (Nakamura et al. 1995a). Thus the clearance rate of $F$. ehrenbergii (body volume $=6.2 \times 10^{4} \mu \mathrm{m}^{3}$ ) is $6.2 \mu \mathrm{l} \mathrm{celI^{-1 }} \mathrm{h}^{-1}$, sufficient to clear the G. mikimotoi population within a day if Favella abundance is $7 \mathrm{ml}^{-1}$ or above (Fig. 4D). Although Hansen (1995) has pointed out that F. ehrenbergii cannot sustain its growth when fed Gyrodinium aureolum (closely related to $G$. mikimotoi), we conclude that $F$ ehrenbergii ingested $G$. mikimotoi actively, increased its abundance, and contributed to the disappearance of the red tide. Other studies have shown the importance of Favella sp. for controlling thecate dinoflagellates (Stoecker et al. 1984).

From 1 to 3 August, when Favella ehrenbergii concentrations increased along with the decline in Gymnodinium mikimotoi (Fig. 4D), the plankton community structure also changed drastically. The abundance of h-dinos decreased rapidly (Fig. 4A, B) and that of autotrophic and heterotrophic nanoflagellates decreased from $2.0 \times 10^{3}$ and $2.2 \times 10^{3} \mathrm{ml}^{-1}$ to $0.7 \times 10^{3}$ and $0.4 \times 10^{3} \mathrm{ml}^{-1}$, respectively (S. Suzuki unpubl). Although not conclusive, these changes seem to be due to ingestion by $F$. ehrenbergii. Furthermore, the abundance of heterotrophic bacteria and picocyano- bacteria increased from $3.0 \times 10^{6}$ and $3.5 \times 10^{5}$ to $4.9 \times$ $10^{6}$ and $5.9 \times 10^{5} \mathrm{ml}^{-1}$, respectively, probably due to the decrease of grazing pressure by heterotrophic nanoflagellates. Thus, $F$. ehrenbergii seemed to affect the nano/pico-sized plankton community structure directly or indirectly in our study area.

Our findings stress the ecological importance of Favella ehrenbergii. However, questions still remain. (1) Why did F. ehrenbergii not devlop during the red tide of 1994 (Nakamura et al. 1995b)? Was the initial abundance of $F$. ehrenbergii too low? (2) Although the red tide of 1995 disappeared by 7 August in the central part of Harima-nada, why did it continue until mid August in the coastal area of Honshu and Shikoku without $F$. ehrenbergii (Nagai pers. comm.)? At present we do not have any clues that could allow us to answer these questions. However, future studies on changes in the life cycle of F ehrenbergii (e.g. timing of excystmont from the sediment) might help to explain these issues.

Acknowledgements. We thank Drs Y O. Kim and R. Suzuki for tintinnid species identification, and $K$. Suzuki and $H$. Kobayashi for support with the field sampling. This study was supported by Grant-in-Aid No. 05640720 from the Scientific Research Fund of the Ministry of Education, Science and Culture, Japan

\section{LITERATURE CITED}

Bandschneider K, Robinson RJ (1952) A new spectrophotometric determination of nitrite in seawater. J Mar Res 11:87-96

Bjornsen PK, Nielsen TG (1991) Decimeter scale heterogeneity in the plankton during a pycnocline bloom of Gyrodinium aureolum. Mar Ecol Prog Ser 73:263-267

Chang J, Carpenter EJ (1985) Blooms of the dinoflagellate Gyrodinium aureolum in a Long Island estuary: box mode] of bloom maintenance. Mar Biol 89:83-93

Dixon GK, Holligan PM (1989) Studies on the growth and nitrogen assimilation of the bloom dinoflagellate Gyrodinium aureolum Hulburt. J Plankton Res 11:105-108

Hansen PJ (1995) Growth and grazing response of a ciliate feeding on the red tide dinoflagellate Gyrodinum aureolum in monoculture and in mixture with a non-toxic alga. Mar Ecol Prog Ser 121:65-72

Heinbokel JF (1978) Studıes on the functional role of tuntinnids in the Southern California Bight. 1. Grazing and growth rates in laboratory cultures. Mar Biol 47:177-189

Honjo $T$ (1994) The blology and prediction of representative red tıdes associated with fish kills in Japan. Rev Fish Sci 2 $225-253$

Honjo T, Yamamoto S, Nakamura O, Yamaguchi M (1990) Annual cycle of motile cells of Gymnodinum nagasakiense and ecological features during the period of red tide development. In: Granéli $E_{1}$ Sundström B, Edler L, Anderson DM (eds) Toxic manne phytoplankton. Elsevier. New York, p 165-170

lizuka S (1972) Gymnodinium type-65 red tide occurring in anoxic environment of Omura Bay. Bull Plankton Soc Japan 1.9:22-33 
lizuka $\mathrm{S}$, Irie $\mathrm{H}$ (1969) Anoxic status of bottom waters and occurrences of Gymnodinium red water in Omura Bay Bull Plankton Soc Japan 16:99-115

lizuka S, Mine K (1983) Maximum growth rate of Gymnodinium sp. (Type-'65), a red tide dinoflagellate, expected under culture conditions. Bull Plankton Soc Japan 30:139-146

Iwasaki H, Kim CH, Tsuchiya M (1990) Growth characteristics of a dinoflagellate Gymnodinum nagasakiense Takayama et Adachi. Jpn J Phycol 38:155-161

Jiménez C, Niell FX. Figueiras FG, Clavero V, Algarra P, Buela J (1992) Green mass aggregations of Gyrodinium cf. aureolum Hulburt in the Ria of Ponteverda (north-west Spain). J Plankton Res 14:705-720

Jones KJ, Ayres P, Bullock AM, Roberts RJ, Tett P (1982) A red tide of Gyrodinium aureolum in sea lochs of the Firth of Clyde and associated mortality of pond-reared salmon. J Mar Biol Ass UK 62:771-782

Koizumi Y, Uchida T, Honjo T (1996) Diurnal vertical migration of Gymnodinium mikimotoi during a red tide in Hoketsu Bay, Japan. J Plankton Res 18:289-294

Murphy J, Riley JP (1962) A modified single-solution method for the determination of phosphate in natural waters. Analytica Chim Acta 27:31-36

Nakamura Y, Sasaki S, Hiromi J, Fukami K (1993) Dynamics of picocyanobacteria in the Seto Inland Sea (Japan) during summer. Mar Ecol Prog Ser 96:117-124

Nakamura Y, Suzuki S, Hiromi J (1995a) Growth and grazing of a naked heterotrophic dinoflagellate, Gyrodinium dominans. Aquat Microb Ecol 9:157-164

Nakamura Y, Suzuki S, Hiromi J (1995b) Population dynamics of heterotrophic dinoflagellates during a Gymnodinium mikimotoi red tide in the Seto Inland Sea. Mar Ecol Prog Ser 125:269-277

Nakamura Y, Umemori T, Watanabe M (1989) Chemical environment for red tides due to Chattonella antiqua Part 2 Daily monitoring of the marine environment throughout the outbreak period. J Oceanogr Soc Japan 45:116-128

Nakamura Y, Watanabe MM (1983) Nitrate and phosphate uptake kinetics of Chattonella antiqua grown in light/dark cycles. J Oceanogr Soc Japan 39:167-170

Negri RM, Carreto JI, Benavides HR, Akselman R, Lutz VA. (1992) An unusual bloom of Gyrodinium cf. aureolum in the Argentine sea: community structure and conditioning factors. J Plankton Res 14:261-269

Neuer S, Cowles TJ (1995) Comparative size-specific grazing rates in field populations of ciliates and dinoflagellates. Mar Ecol Prog Ser 125:259-267

Paasche E, Bryceson I, Tangen K (1984) Interspecific variation in dark nitrogen uptake by dinoflagellates. J Phycol 20: $394-401$

Partensky F, Vaulot D, Couté A, Sournia A (1988) Morphological and nuclear analysis of the bloom-forming dinoflagel-

Responsible Subject Editor: J. Dolan, Villefranche-sur-Mer, France lates Gyrodinium cf. aureolum and Gymnodinium nagasakiense. J Phycol 24:408-415

Pingree RD, Pugh PR, Holligan PM, Forster GR (1975) Summer phytoplankton blooms and red tides along tidal fronts in the approaches to the English Channel. Nature 258: $672-677$

Porter KG, Feig YS (1980) The use of DAPI for identifying and counting aquatic microtauna. Limnol Oceanogr 25: 943-948

Rassoulzadegan F (1978) Dimensions et taux d'ingestion de particles consommées par un tintinnide: Favella ehrenbergii (Clap. et. Lachim.) Jorg., cilié pelagique marin. Ann. Inst Oceanogr Paris 54:17-24

Sherr EB, Sherr BF, Fallon RD, Newell SY (1986) Small aloricate ciliates as a major component of the marine heterotrophic nanoplankton. Limnol Oceanogr 31:177-183

Solórzano L. (1969) Determination of ammonia in natural waters by the phenolhypochlorite method. Limnol Oceanogr 14:799-801

Spitter P (1973) Feeding experiments with tintinnids. Oikos 15(Suppl) : 128-132

Stoecker DK, Davis LH, Anderson DM (1984) Fine scale spatial correlations between planktonic ciliates and dinoflagellates. J Plankton Res 6:829-842

Stoecker DK, Gallager SM, Langdon CJ, Davis LH (1995) Particle capture by Favella sp. (Ciliata, Tintinnina). J Plankton Res 17:1105-1124

Strickland JDH, Parsons TR (1968) Determinations of silicate in seawater. In: A practical handbook of seawater analysis Bull Fish Res Bd Can 167:137-138

Takayama $H$, Matsuoka $M$ (1991) A reassessment of the specific characters of Gymnodinium mikimotoi Miyake et Kominami ex Oda and Gymnodinium nagasakiense Takayama et Adachi. Bull Plankton Soc Japan 38: $53-68$

Uye S, Takamatsu K (1990) Feeding interactions between planktonic copepods and red-tide flagellates from Japanese coastal waters. Mar Ecol Prog Ser 59:97-107

Verity PG, Stoecker DK, Sieracki ME, Burkill PH, Edwards ES, Tronzo CR (1993) Abundance, biomass and distribution of heterotrophic dinoflagellates during the North Atlantic spring bloom. Deep Sea Res II 40:227-244

Wood EP, Armstrong FA, Richards FA (1967) Determination of nitrate in seawater by cadmium-copper reduction to nitrite. J Mar Biol Ass UK 47:23-31

Yamaguchi M, Honjo T (1990) Effects of temperature, salinity and irradiance on the growth of the noxious red tide flagellate Gymnodinium nagasakiense (Dinophyceae). Nippon Suisan Gakk 55:2029-2036

Yentsch CS. Menzel D (1963) A method for the determination of plankton chlorophyll and phaeophytin by fluorescence. Deep Sea Res 10:221-231

Manuscript first received: January 10,1996

Revised version accepted: March 13, 1996 